\title{
ZEVEN DIERENVERHALEN
}

OPGETEEKEND EN BEWERKT

DOOR

G. A. N. SCHELTEMA.

\section{INLEIDING.}

De volgende bijdrage is onvolledig.

$\mathrm{Zij}$ is dit in de toegevoegde opmerkingen.

Edoch, om redenen voor den lezer van geen belang, is het den aanbieder niet mooglijk geweest zijne bijdrage beter te bewerken, dan hij het nu gedaan heeft.

Hij meende echter de verhalen niet langer onder zich te moeten houden en biedt hen dus aan zooals ze nu bewerkt zijn, gedachtig aan het spreekwoord: "beter een half ei dan een leege dop."

\section{HERKOMST.}

Voor een goed aantal - minstens vijftien - jaren woonde te Singapoera in Kampoeng Tembaga een maleier, die na den hadj te hebben volbracht en in de heilige steden veel kundigheden te hebben opgedaan, naar huis was getrokken en zich onder den naam van hadji Masroep te genoemder plaatse had gevestigd als onderwijzer, en wiens school weldra druk bezocht werd.

Een groote woning had hij betrokken, want niet minder dan veertig kinderen van acht- tot veertienjarigen leeftijd waren door hun ouders aan hem overgegeven in de hoop van deeglijk onderwijs van hem te zullen ontvangen.

Hij behandelde de kinderen niet al te zoetsappig maar schroomde niet hen, zoo noodig, aan den lijve te bestraffen, - wat zeker nog al eens noodig zal zijn geweest, te oordeelen naar de marteling, voor zulke jonge snuiters gelegen in de regeling door den g o e roe getroffen. 
Met een leegen maag moesten ze des morgens om zes uur in de school aanwezig zijn - een volle buik verwekt slaaplust! -; tot elf uur hield het mengadji aan; alsdan werd den kinderen een paar uren rust gegund, om daarop de werkzaamheden te een ure te hervatten tot drieën.

De vloer van het schoollokaal - tempat mengadji - is belegd met matten, vervaardigd door des goeroe's huisvrouw. Daarop nemeu de leerlingen - a $\mathrm{nak}$ moerid - in twee rijen plaats, zoo dat er tusschen hen een gang openblijft, waarin de goeroe zich op en neer beweegt.

Alle zijn te gelijker tijd aan het reciteeren. De ouderen helpen daarbij de jongeren. Zoo schieten ze goed op, uitgezonderd enkele dommen er onder die op hun veertiende jaar nog niet tamat mengadji zijn, en het alsdan maar verder moeten opgeven.

Knappen, jongens met aanleg, treft men er ook onder aan. Deze kunnen des verlangd doorstudeeren, waartoe de hadji hun in een andere woning gelegenheid geeft. Zij gaan dan over tot het batja kitab.

Donderdagsavonds - mala m Djoe ma ${ }^{\mathrm{a}} \mathrm{at}-$ komen de kinderen te half zeven ook bijeen en reciteeren dan tot negen uur. Op dat uur wordt met lesgeven uitgescheiden en nuttigt de goeroe zijn avondmaal. Is dat op, dan laat hij zich door eenige der kinderen pidjetten, onder welke behandeling hij hun verhaaltjes vertelt, hetgeen enkelen niet belet zoo slaperig te worden, dat ze den volgenden dag niet in de les versehijnen, - daarop door den hadji zelf uit hun huis worden gehaald en, in de school gekomen, eene duchtige afstraffing bekomen. -

Onder die verhaaltjes nu behoorden de volgende dierfabels, die ik heb opgeteekend uit den mond van een van $\mathrm{hadji} \mathrm{Ma}^{s}$ roep's gewezen leerlingen, welke mij den langsten tijd van mijn ruim elfjarig eerste verblijf in Nederlandsch-Oostindië als bojof djongos - naar het verschillend taalgebruik in Deli en op Java - zoomede als koki, heeft gediend. Deze ex-leerling had behoord tot hen, die 't met hun mengadji nooit tot tamat hadden weten te brengen, doch voor des hadji's verhalen was hij in 't bezit van een des te sterker geheugen.

Mij toevalliger wijze gebleken zijnde, dat hij verhalen wist waarin diêren eene rol spelen, heb ik ze hem mij laten oververtellen en onder 't verhaal er aanteekening van gehouden. Allerprettigste oogenblikken waren mij dat, want niet alleen klonken 
die verhalen zoo echt eenvoudig in het naïeve maleisch en kwam hun geest daardoor zoo goed uit, maar daarenboven genoot de verteller, al vertellende, zelf zoozeer van dien geest, dat hij vaak van den eenen gullen lach in den anderen verviel.

Want de inlander, hoe strak zijn gelaat in des europeeërs dienst gemeenlijk sta, heeft een ongemeen sterk ontwikkeld gevoel voor wat geestig is; indisch-geestig natuurlijk.

Onder zijn inlandsche vrienden had de naverteller een anderen naam dan onder ons, europeanen, die hem - tenger als hij was, vooral toen hij zijn "heeren"-dienst pas begon - Si Ketjil noemden. Dien kampoengnaam ben ik echter vergeten. Zijn vader was een bawejanner of bojan - gelijk men in Deli den engelschen nazegt - , zijne moeder eene singapoersch-maleische.

\section{De verhalen.}

\section{Van den kat.}

a. Met tijger en beer. - De kat had den tijger en beer in de leer genomen. Al wat hïzelf kende onderwees hij aan deze beiden: sluipen, springen, gluren, wat niet al. En zoowel aan den een als aan den ander. In een punt maakte hij onderscheid tusschen zijn beide leerlingen: den beer gaf hij ook les in het boomklimmen, en die kunst onthield hij den tijger.

"Waarom", vroeg deze, "leert ge mij dat niet ook?"

"Omdat", antwoordde de kat, "als gij dat ook kent, ge van boven uit den boom te weten kunt komen waar menschen wonen, en deze alsdan gevaar loopen van door u te worden opgegeten." (De beer eet naamlijk geen menschen, maar rijt hen alleen in tweeën.)

De tijger dit vernemende, was woedend, en zwoer den kat eeuwige haat.

"Niet alleen hem, tot zelfs zijn uitwerpselen zal ik opvreten, waar ik er ook aantref", zoo zwoer hij.

Om die reden neemt voortaan de kat de voorzorg zijne faeces in te graven. -

b. Met lampongschen a ap. - De lampongsche aap gehoord hebbende van de bekwaamheden die de kat wist mee te deelen, begaf zich naar hem toe en verzocht ook bij hem in de leer te mogen komen. Dit werd hem echter geweigerd. 
"Waartoe zou ik u opnemen?" merkte de kat aan. "Gij, een aap, les nemen bij mij, een kat: wat zou dat kunnen geven?"

"En den tijger en den beer hebt ge wel onderwezen!"

"Dat is een heel ander geval: beer en tijger leven op den grond: hoe zouden zij zonder mijn onderricht hun levensonderhoud vinden, dat ze hier beneden moeten zoeken, vaak niet zonder gevaar. Gij komt hier echter om van gebrek: uw voedsel vindt ge in de kruinen der boomen, en ge zijt bang als er een mensch aankomt: ziet ge er een, dan vlucht ge ijlings omhoog. Neen, u geef ik geen les."

En daarmee kon de aap heengaan. -

\section{Van den kantjil.}

a. Met tijger. - (Dit is de oorsprong der veete tusschen tijger en kantjil.) - In den beginne waren ze goede vrienden. Toen de vrouw van den kantjil had gekraamd, lieten ze hun kind eens thuis achter om in het bosch eten te zoeken. Weldra komt de tijger in kantjil's huis en vreet het kind op. Daarna gaat hij het bosch in.

Kantjil en zijn vrouw treffen nu bij te-huiskomst hun kind niet meer aan. Zij zoeken door hun heele huis en daar buiten, en vinden hun kind niet. Zij weenen. Kantjil zegt tot zijne vrouw :

"Pas goed op 't huis; ik ga in 't bosch zien of de kleine daar al spelende in verdwaald is."

Zoo gesproken hebbende verlaat kantjil haar.

Aldra komt de tijger weer terug. Hij treft kantjil's vrouw slapende. Uitgeput van vermoeinis van het zoeken naar ' $t$ kind, is ze in een diepen slaap gevallen en hoort niets. De tijger bewatert haar linker oog, goed nat. Daarop gaat hij heen.

Kantjil komt thuis, roept zijne vrouw: geen antwoord. Hij gaat naar haar legerstee en ruikt een urienlucht. Zijn vrouw gewekt hebbend, zegt hij haar:

"Waarom ween je?"

"Ik ween niet."

"Hoe komt je oog dan nat?"

De kantjil herkent nu de reuk van tijgerpis.

"Is hier iemand binnen geweest?"

"Ik weet niet, ik heb geslapen, ik weet van niets af."

Kantjil zei daarop: 
"Ons kind zal wel door den tijger zijn opgevreten : ' $t$ is beter dat ik geen vrienden meer met hem ben. Nu, vrouw, ga ik er op uit om den tijger te zoeken. Pas goed op 't huis, en als er lui komen, zeg dan alleen maar dat ik uit ben gegaan; meer niet."

Hierop vertrekt kantjil. -

b. Met tijger en wespen. - Niet lang daarna ontmoet hij den tijger. Deze spreekt hem vriendlijk toe:

"Waarheen kantjil?"

"O, ik ga eten zoeken, anders niet."

"Ik wil met je meegaan."

De kantjil spreekt af:

"Best, maar ik loop vast vooruit, jij komt achter na; ik zal je, aan den kant van den weg zittende, opwachten."

Toen de kantjil aan het zoeken van een wespennest. Hij vindt er een ter zijde van den weg, waar nog wespen in.waren. Dit nest was aan den voet van een grooten boom gemaakt, zooals door de wespen gedaan wordt. De kantjil zet zich daarop neder.

Nauwlijks zit hij, of de tijger komt aanloopen, buiten adem: "Kantjil, waar ben je toch gebleven, ik heb je overal gezocht." "Ja, rimau, ik heb aldoor op je zitten wachten, waar heb je toch al dien tijd gezeten!"

De tijger zegt:

"Ik zocht je, maar kon je nergens vinden."

"O $\mathrm{O}$, zegt kantjil, "wat is dat mooi!"

"Wat meen je?"

"Hier dat orgel: zoo'n mooie wijs!"

"Ik hoor er niets van."

"Dat komt, je moet er vlak bij zijn."

De tijger, dichtbij gekomen, hoort nu van de plaats waar de kantjil zit zoo'n lieflijk geluid komen, dat hij onwilkeurig uitroept:

"Kantjil, wat een fraai geluid, net als van een soeling!" "Ja", zegt de kantjil, "ik zit hier op het orgel van mijn heer te passen."

"Zou ik daar ook eens op mogen spelen?"

"Och, wat zou dat geven?"

"Eventjes maar."

$" \mathrm{Nu}$ goed, maar dan moet je mij eerst wegwerpen, een depa of tien hier van daan. En als je het orgel goed wilt hooren, denk er dan om dat je er tegen blaast!" 
"Opperbest", zegt de tijger, pakt den kantjil aan, en werpt hem een flink eind weg.

De tijger daarop aan het blazen. Geen minuut verloopt of de wespen komen woedend naar buiten en vallen op den tijger aan, dien zij zoo onbarmhartig steken, dat hij in minder dan geen tijd er rampzalig uitziet.

"O", roept hij huilend uit, "als ik hem nu te pakken krijg! Dan spreek ik niet meer met hem maar vreet hem zonder omslag op."

Maar de kantjil was noch te zien, noch te hooren. Zorgvuldig verscholen, lachte hij hartlijk om het ongeluk van den tijger. -

c. Met tijger en slang. - Daarop verwijderde hij zich en liep voort tot hij een slapende reuzeslang aantrof. Hij ging op haren kop zitten.

De tijger kwam aan en vroeg hem:

"Waar zit je daar op; wat is dat voor een mooi ding?"

"Een gouden kistje dat ik voor 's vorsten egade moet bewaken."

"Laat mij dat een oogenblik doen!"

"Och jij, wat wil je toch altijd met mij: overal waar ik ben, moet jij ook daadlijk komen: neen, het kan niet. Alleen mij vertrouwt de vorstin dat werk toe."

De tijger houdt aan :

"Een oogenblikje maar!"

"Hoe zou dat gaan: ik ben klein, jij zoo groot: 't kistje is zoo erg sterk niet."

"Toe nou!"

$" \mathrm{Nu}$, een klein oogenblik, maar gooi mij eerst een goed eind het bosch in. Daarna, als ik een schreeuw geef, ga er dan op zitten."

Zoo gezegd, zoo gedaan. Op de uitnoodiging van den kantjil om te gaan zitten, zit de tijger neer, maar de slang had juist haar bek open, waar de tijger in zijn vreugd geen acht op sloeg. Op 't zelfde pas gaf een vervaarlijk gehuil echter aan, dat de tijger er weer was ingeloopen. Zijn schaamdeel was in den bek der slang terechtgekomen, en werd door deze voor de helft afgebeten.

Schreiend en weeklagend ging de tijger - die tot heden de sporen er van draagt - heen: op weg om den inmiddels gevluchten kantjil op te sporen. -

d. Met tijger en put. - Deze was doorgeloopen tot waar hij een zeer diepen put antrof, die juist droog was. Hij sprong daarin neer, en deed alsof hij sliep. 
't Duurt niet lang of de tịger komt daarbij. Deze vraagt:

"Kantjil, wat doe je daar onder; ben je niet bang daar om te komen?"

"Hoe kan je zoo iets vragen! Weet je dan niet dat morgen het jongste gericht wordt gehouden? Alles wordt daarbij het onderst boven gekeerd. Als je dus nu in den kuil bent, dan kom je morgen boven te liggen, en de lui die boven blijven krijgen morgen de wereld op zich."

"Is 't waar!?"

"Ja, zeker is 't waar, en als je 't niet wil gelooven, dan zal je 'et morgen om acht uur wel ondervinden, als 'et laatste oordeel aanvangt."

De tijger gelooft het en laat zich omlaag glijden. Beneden vraagt hij den kantjil, of het daar angenaam is om te verblijven?

"Ja, dat gaat wel, we hebben hier nog al de ruimte."

Een moment daarna bestijgt de kantjil 's tijgers rug. Deze begrijpt niet wat de kantjil in 't zin heeft en laat hem begaan. Kantjil neemt een sprong naar boven en is er uit. Daarop de tijger aan 't razeu.

"Ja", zegt de kantjil, "jij, zoo'n groot beest, kan mij niet bedriegen, en ik doe het jou wel, zoo klein als ik ben", en verlaat hem.

De tijger stelt wanhopige pogingen in 't werk om er uit te komen, slaagt er niet in, en blaast er ten slotte zijn laatsten adem in uit. -

e. Met bruiloftsgasten. - Kantjil komt in het vervolg van zijn tocht aan een huis waar voor de, den volgenden dag te vieren bruiloft alles in gereedheid is gebracht. De moede menschen zijn op het punt van naar bed gaan.

Hij wacht tot ze slapen en klimt dan op het dak, van waar hij door de rookgeleiding naar binnen komt. Velerhande lekkers staat daar in doelangs klaar. Kantjil eet alles gelijk op, en vervult de ledige doelangs met zijn gevoeg. Vervolgens begeeft hij zich naar de keuken. Hier draait hij alle huisraad het onderste boven. Aan den onderkant maakt hij zijn handen zwart door ze over het roet te strijken, en spoort dan het vertrek der bruid op, waar hij binnen treedt. Met zijn vuile handen smeert hij de bruid haar gezicht in, die doorslaapt. Daarna bevuilt hij, op gelijke wijze alles wat in en aan het huis is, waarop hij de vrouw die in 
het vertrek naast de bruid slaapt, gaat wekken. Hij zet zich voorzichtig op den punt van haar neus en laat een wind, rent naar boven op den nok van 't huis, en neemt een klein kussen daarheen mee.

De stank dringt in de neus der vrouw door: zij ontwaakt, en gaat de kamer der bruid binnen die ze pikzwart ziet. Verschrikt, roept zij al de huisgenooten bijeen. Deze, bang door het zwarte gezicht der bruid, verbazen zich over haar gelaatskleur, nog zoo kort geleden aanvallig blank. Zoo ontstaat groot rumoer. Geen andere gedachte bezielt een ieglijk, dan dat de bruid een spook is geworden. Van haar gaan ze naar de lekkernijen kijken en vinden daar nog slechts faeces voor liggen. Nieuwe ontsteltenis. Verder trekken ze naar de keuken, waar ze alles het onderste boven vinden. Daar worden kantjil's voetstappen in de wijd en zijd verbreide asch herkend.

De kantjil, gezocht, zit ongezien rustig boven. Nadat het heele huis te vergeefs naar hem doorzocht is, wordt hij ten laatste op den nok aangetroffen.

"Ha", zoo luidt het als uit éen mond, "daar is de dief die ons vleesch, enz. heeft opgegeten. Morgen trouwen - en geen stukje vleesch meer in huis!" Alle lui gaan te gelijk op hem af.

De kantjil smijt zijn kussen neer, dat zij houden voor den kantjil-zelf, die valt. IJlings stuiven alle er op af, om te bevinden dat het maar een kussen is.

Kantjil zit middelerwijl nog boven. Enkele klimmen daar heen, en vatten hem. Hoe had hij kunnen wegkomen? Dat ging niet meer: lui onder en lui boven!

Zij beloven hem morgen te zullen slachten als straf voor al zijn euveldaden.

Kantjil wordt in een koeroengan gezet en weent den ganschen nacht door.

Een kikker komt omtrent den koeroengan, welken kantjil aldus toespreekt:

"Vorsch, help mij toch, ik weet geen raad meer."

"Hoe kom je dáar nu in?" vraagt hem de kikker.

"Ja, ik heb de koewih penganten opgegeten en ben gevangen en moet morgen geslacht worden."

De kikker geeft raad:

"Morgen om zes uur, als de lui komen om je te slachten, dan ga je stijf uitgestrekt liggen, en van nu af laat je het spung uit je 
mond loopen, dat het morgen stinkt. Dan denken de menschen op den reuk af dat je dood bent en zullen je wel in het bosch weggooien."

Den volgenden dag komen alle hens opzetten met messen en touwen en willen hun werk aan den kantjil beginnen. Nabij hem gekomen, zeggen ze:

"O kijk die kantjil slapen: zijn kop zus, zijn handen zoo: o, slaapt een kantjil zoo; dat zie ik nu pas voor het eerst: een slapenden kantjil!"

Ze vatten hem daarop aan.

"Hij is dood: hij is al stijf!"

"Wat dood: hij slaapt maar!"

Daarop wordt hij omgedraaid, bekeken, betast: de kantjil is zoo stijf als een hout.

"Dood!" is 't besluit: "als hij levend was, zou hij buigen of trachten te ontkomen: hij is geheel stijf en stinkt ook al."

Ten slotte is iedereen er van overtuigd dat hij dood is.

"Ja", zeggen er, "als hij dan toch dood is, hebben we der niets meer aan. Als we hem toch slachten en den gasten dood vleesch voor zetten, dat gaat niet aan. Neen, bewaren geeft niets: beter is 'et, nu hij dood is, hem maar weg te gooien.“

Daarop beetgepakt en weggeworpen, springt hij waar hij valt op, lacht luid, en rent hard het bosch in.

Het een en ander hoorende en ziende, staat de lieden hun begrip er voor stil, dat de kantjil, die toch goed dood was, nu in eens weer leeft, en naar huis gaan ze waar ze alles aan de achtergeblevenen vertellen.

De bruigom was middelerwijl verwittigd dat zijn bruid er dien nacht als een spook had uitgezien. Hij zei tegen zijn ouders:

"Laat 't er dan maar bij; dan huw ik haar liever niet: misschien wordt ze later spook. Laten de onkosten dan maar voor niets gemaakt zijn.". -

\section{OPMERKINGEN.}

„...truly native stories... form a rich store of subjects for comparison with the folk-tales of other parts of the world."

Codrington's „Milanesians", ch. XIX.

De voorname trekken in bovenstaande verhalen heb ik vergeleken met de volgende werken, die verder aangeduid worden met de nevens hen aangegeven verkortingen: 
RdV. I. . . V Van den vos Reynaerde, uitgegeven door dr. W. L. van Helten, Groningen 1887.

RdV. II. . . Reinaard de Vos, bewerkt door Prudens van Duyse, Roeselare 1891.

ST. . . . . Sangireesche teksten, uitgegeven door dr. N. Adriani, Bijdr. kon. inst. deel 42.

K. I . . . S Serat kantjil van Amongsastra, overzicht van dr. J. Brandes, Tijdschr. Bat. Gen. deel 37.

P. I. . . Hikajat pelandoek djinaka, uitgegeven door H. C. Klinkert in 1885 , overzicht van dr. J. Brandes, a. v.

K. II . . . Serat kantjil, uitgave van G. C. T. van Dorp, overzicht van dr. J. Brandes, a. v.

P. II. . . . Pelandoek djinaka, uitgegeven door H. C. Klinkert in 1893 , overzicht van dr. J. Brandes, a. v.

Pk.. . . . . . De Atjèhers, door dr. C. Snouck Hurgronje, BataviaLeiden 1894, deel II, $\S 6$ : Plandō ${ }^{\varsigma}$ kantjé. 1

Na. . . . . Als voren: Hikajat Nathroean adé of Kit ${ }^{\text {h}} a h$ Hiweuën. GF. . . . . Fabelen (enz.) der Galèlareezen, uitgegeven door H. van Dijken en M. J. van Baarda, Bijdr. kon. inst. dl. 45. PT. . . . . Pakěwa'sche teksten, vertaald door dr. H. H. Juynboll, als voren.

Het optreden van een dier als leermeester, zooals in mijn $\mathrm{n}^{\circ} \mathrm{I} a$ de kat het doet, vindt zijne wedergaden in GF. $\mathrm{n}^{0} 6$ waar de kikvorsch springles geeft aan den $\mathrm{klabang}$, en in Na. $\mathrm{n}^{\circ} 17-$ overeenkomende, volgens opgaaf ald., met het verhaal op bl. 301 der Kalila dan Damina, ed. Gonggrijp — waar de tijger leerling is van den jakhals.

Dat de kat een geleerd dier is, erkent ook koning Nobel (Rd V. I v. 924 en 942), en daar als hier blijkt haar die naam te worden toegelegd om de geslepenheid, haar van nature eigen; in Na. $n^{0} 10$ treedt zij op als rechter tusschen den pland $\bar{o}^{5}$ en den moerōng-vogel (vg. Kalila dan Damina, ed. Gonggrijp, bl. 215). Van haar klimkunst in 't bijzonder gewagen: GF. $\mathrm{n}^{\circ} 5$, zoowel in 't verhaal der katten van 't geen zij gezien hadden uit "de toppen der boomen" waar zij in geklommen waren, als in hun vlucht naar die schuilplaats toe, als de honden op haar afkomen; RdV. I v. 1789*, waar Reinaart, tot den galg veroordeeld,

1 Het in den tekst van 't genoemde werk voorkomende kantji behoort volgens de daarbij behoorende „Verbeteringen en aanvullingen" te zijn k antjé. 
zegt dat Tibert er maar op moet klimmen om er de lijn aan te hangen; en RdV. II bl. 152, waar beschreven staat hoe Tibert met Reinaarts vader uit zijnde en overvallen wordend door een jachtstoet, den vos in den steek laat en zichzelf in een boom redt.

Eene andere uitlegging van het feit dat de tijger niet kan klimmen, dan de hier gegevene als zoude hem de kat dit met opzet niet geleerd hebben, bevatten de regels die ik vroeger schreef in mijne "Schetsen uit Deli" (Stuk II, Bat. Nwsbl. 1/7-'93-176): "... de tijger houdt niet veel van boomen. Hij kan er niet eens in klimmen; dat komt, zegt de inlander, omdat het kattengeslacht geschapen is vóor dat der tijgers: het zijn de katten, die aan de tijgers de kunst hebben moeten leeren, maar dat klimmen hebben de katten er met den besten wil niet in weten te krijgen." Dat eerder geschapen zijn werd mij aldus uitgedrukt: "Koetjing lebih toewa dari rimau".

Van een lijnrecht tegenovergesteld gevoelen geven de woorden blijk, die ik ontleen aan Van der Toorn's "Het animisme bij den Minangkabauer der Padangsche Bovenlanden" (Bijdr. kon. inst., deel 39 , bl. 73 , noot 1): "Een uitvloeisel van het begrip, dat eenig dier uit een ander kan voorkomen, is b. v. het verbod, hier en daar bestaande, om de kat bij haren naam te noemen, wijl men gelooft, dat zij uit een koningstijger ontstaan is."

Evenwel schijnt zich K. I $\mathrm{n}^{0} 14 f$ bij de door mij medegedeelde opvatting aan te sluiten; immers daar staat: dat de boschkat "zich altijd zoo gewichtig, oudeheerachtig [ik spatiëer], pedant aanstelt." Om op te letten, is mede dit laatste woord, dat met zijne beteekenis van "schoolvossig", "meesterachtig", terugvoert naar ons uitgangspunt, hetwelk was: de rol van leermeester, in de dierfabel aan de kat toegelegd. -

Van 's tijgers onbedrevenheid en des aaps vaardigheid in het klimmen - het onderwerp, voor een deel, van mijn $n^{\circ}$ I $b-$ trekt $K$. II $n^{\circ} 5$ partij : als de tijger den aap voorspeld heeft dat zijn geslacht voortaan steeds door de tijgers verslonden zal worden, dan luidt des laatsten antwoord : "als zij ze kunnen pakken, dan is het goed".

Nog wordt daar knap gebruik gemaakt van het verschil in voedselvindplaats tusschen aap en tijger - het onderwerp, ten anderen deele, van mijn $\mathrm{n}^{\circ}$ I $b-$ : met aaneengebonden staarten kunnen zij niet samenleven wijl de plaatsen uiteenloopen waar de een en waar de ander zijn voedsel van daan haalt. 
Des aaps klimvaardigheid is nog tot werkend motief gebezigd in : PT. $\mathrm{n}^{\circ} \mathrm{I}$, waar de naar boven geklauterde aap zich te midden der vergaderden laat vallen; ST. ${ }^{\text {os }}$ II $b, c$ en $f$, waar de aap door in de boomtoppen te klimmen aan den haai en den reus $(b)$, dan wel aan den reus alleen ( $c$ en $f$ ) ontkomt; GF. $n^{\text {os }} 1$ en 2 , waar resp. de krokodil den boom bewaakt in welken de aap hem ontvlucht is, en de aap pisangs plukt voor den landschildpad, evenwel ze allen zelf verorberend; P. II $n^{0} 4$, waar de aap om den schopkamp van olifant en dwerghert te zien in een bĕringin plaats neemt; en P. I $n^{0} 4$, waar de jakhals aan den aap verwijt, dat hij dezen diens uitschelden van het dwerghert wel zou laten voelen, als hij maar niet boven in een boom zat.

Met het uit dit laatste tevens blijkend onvermogen van den jakhals om te klimmen, stemt wederom dat de tijger - die, als boven bleek, bij dezen in de les is geweest - die kunst niet verstaat.

Dat de in mijn verhaal vermelde aap bepaaldelijk een sija mang is, zit 'em daarin dat deze de beste klimmer is onder zijn rasgenooten, om welke reden hij ook veel op 't klapperplukken wordt afgericht. In P. I n ${ }^{\circ} 9$ treedt o. m. ook een sija mang op, en het onder Pk. $n^{\circ} 11$ aangeduide verhaal heeft ook "klapperapen" onder zijn handelende personen.

Wat de gelofte van deu tijger jegens de(n) kat betreft, zelfs diens fa eces op te eten waar hij die maar vindt, hieraan maant de uitdrukking van den leeuw in $P$. I ${ }^{\circ} 5$ : dat hij het dwerghert zal opeten "dĕngan tahínja", hoezeer dit niet op 't zelfde neerkomt wat in mijn verhaal is bedoeld.

Veeten tusschen dieren, zoo gemeen in de hun betreffende fabels - "La discorde a toujours régné dans l'univers", zegt (b. 12 , f. 8) De la Fontaine - komen vooropgesteld voor om aanleiding tot die fabels te geven: zie om daarvan een enkel voor de hand liggend voorbeeld bij te brengen, mijne verhalen sub II $n^{\text {os }}$ $a-d$. Maar zij komen ook zoodanig voor, dat haar bestaan voortvloeit uit het gedane verhaal. Van deze laatste soort fabels strekken vele als verklaring door den eenvoudigen mensch van wat hij in de natuur opmerkt: als brokstukjes natuurlijke historie der ongeleerde volken̂.

Stalen van deze soort leveren mijne verhalen $\mathrm{n}^{\text {ss }} \mathrm{I} a$ en $I I c$ : het eerste verklarende, waarom de kat (die ik beter deed in 't verhaal

6e Volgr. VII. 
een "hij" te noemen; men zie de noot van dr. Brandes bij K. I $\mathrm{n}^{\circ} 10$, luidende — voor zoover noodig — : "In dierenvertellingen gaat het kwalijk aan het grammaticaal geslacht der benamingen... vol te houden. Deze opmerking werd reeds voor dezen door velen gemakt...."; in $\mathrm{RdV}$. is Tibert een kater: I v. 96 , II bl. 151) de gewoonte heeft hare faeces in te graven; het andere, waarom de tijger zoo'n klein uitwendig schaamdeel heeft. Hiertoe behooren al verder: GF. $\mathrm{n}^{\text {os }} 5,9,19$ en 31 , resp. verklarende: waarom de katten bang zijn voor de honden; waarom de menschen op hun hoede moeten zijn voor slangbeten; waarom de honden en wilde varkens elkaar vijandig gezind zijn; waarom de kat de door haar gevangen muizen eerst in den kop bijt voor zij ze opeet; ST. $\mathrm{n}^{\circ}$ XII, op eene andere wijze verklarend waarom de varkens en honden op elkaar gebeten zijn; en $\mathrm{RdV}$. I v. $3156 \mathrm{vlgg}$.: de reden mededeelende waarom wolf en beer zulke schapenmoorders zijn. -

Overgaande tot mijn verhaal $n^{\circ}$ II $a$ valt allereerst op te merken dat het optreden van eenig dier als man en vader, dat dekantjil daarin doet, als van de natuur afgezien, een heel gewoon iets is in de dierfabel; bepaalde gevallen tot toelichting - alle op te noemen gaat niet - doen zich in het vervolg wel van zelf voor.

Ongerechtigheid aan vrouw en kinderen, als hier kantjil's vrouw en kind weervaart, ondervindt in $\mathrm{RdV}$. I v. 64 vlgg. de wolf: immers beklaagt hij zich dat Reinaart overspel heeft gepleegd met zijne wolvin, en zijne welpen heeft bewaterd, zoo dat twee hunner voor levenslang er blind door zijn. Opmerklijk is 't, dat wat de tijger an het hoofd van kantjil's vrouw bepist ook juist haar oog is.

Het opeten der jongkjes komt meer voor: zoo ST. $\mathrm{n}^{0}$ XIV : de slang verorbert alle kuikens eener hen; RdV. I v. 384 volgg.: Reinaart heeft elf der vijftien kuikens van Kanteklaar opgegeten; K. II $n^{\circ} 6$ : kantjil heeft alle jonge tjelengs vermoord, om hem te verderven gaat nu de zeug - eene weduwe - hem achter op. In zoover "alle" biggen hier worden omgebracht stemt dit verhaal met ST. $\mathrm{n}^{\circ} \mathrm{XIV}$; in den trek dat het er "elf" waren sluit het zich aan bij RdV. I v. 384 vlgg.; het laatste motief heeft het met mijn $\mathrm{n}^{0}$ II $a$ gemeen. Nog behoort ST. n ${ }^{\circ}$ VIII vermeld: daarin is 't een aap die 's konings kind opeet!

Het bevuilen dat de tijger's k a tjil's vrouw doet, doet kantjil in mijn $n^{\circ}$ II $e$ op zijn beurt de door hem leeggegeten doelangs, 
enz. en de wijze waarop hij in datzelfde verhaal de baboe der vrouw wekt, is van dezelfde soort hoon al evenmin vrij. 's Tijgers bevuilen van vrouw kantjil's hoofd, doet de euveldaad toenemen in ergheid. Het is dr. Brandes die ons in een noot op $\mathrm{K}$. I n ${ }^{0} 7$ aan die moreele gevoeligheid van den inlander voor zijn hoofd herinnert, naar aanleiding van een krokodil die van den kantjil een tik op zijn kop krijgt. Erger nog maakt het dwerghert het in dit opzicht met den reus in P. II $\mathrm{n}^{\circ} 2$, wien hij op het hoofd gaat staan, van daar af de tijgers en geiten oproepend hem te bevuilen, waar zij dan hevig gevolg aan geven. GF. $n^{\circ} 26$ bevat ook eene bevuilingsgeschiedenis: daar is het de bromvlieg die, na de everzeug in het ongeluk te hebben gestort, haar lijk nog dezen smaad aandoet. Aan des dwergherts opzet om den tijger aan 't eten van uitwerpselen te krijgen, beschreven in $\mathrm{K} . \mathrm{I} \mathrm{n}^{0} \mathrm{l}, \mathrm{K}$. II $\mathrm{n}^{\circ}$, Pk. $\mathrm{n}^{\circ} 5 \mathrm{en}$, met schildpad versus aap, in den te laatstgenoemder plaatse bedoelden bantenschen dongeng, is zeker de medebedoeling van daardoor smaad te doen lijden niet vreemd. Door den aankondiger in de Indische Gids 1890 , bl. 563 vlgg. van de sub K. I bedoelde $\mathrm{K}$ a n tj il-uitgave wordt verband gezien tussehen dit bruffeldrek-eten en Bruins honigraten-eten op Reinaarts aanraden, zie RdV. I v. 536 vlgg. -

Het verhaal van het wespennest $-\operatorname{mijn} n^{\circ}$ I[ $b$ - noemde dr. Brandes in P. II bl. 384 "een belangwekkend verhaal“, daarbij refereerende aan zijne aanteekening ad P. II $n^{\circ} 7$. Dr. Juynboll (die de geschiedenis van het bijenuest - want in de door hem vertaalde verhalen komt bij uitzondering deze episode voor als eene bijengeschiedenis - "merkwaardig" noemt) heeft in PT. bl. 328 den inhoud van dr. Snouck's noot 2 bij Pk. $n^{\circ} 5$ met evengezegde aanteekening vereenigd. Hieruit blijkt dat het tot nog toe bekende vertelveld dezer fabel van niet mindere uitgebreidheid is dan als volgt: Galèla, Boeloe, Pakewa, Sangir, Preanger-regentschappen, Banten, het woongebied der nederlandsch-indische maleiers, Atjeh, Tjam, Kambodja en Annam. Door hare aanwezigheid onder mijne verhalen staat nu ook hare bekendheid te Singapoera vast, en erlangt deze reeks daardoor een bepaalden verbindingsschakel.

Dat in mijne lezing de tijger in het wespenuest een fluit denkt te hooren, de kantjil het een orgel noemt, maar deze genen toch aanraadt er op te blazen, kàn aan dooreenwarring van twee afwijkende voorstellingen worden toegeschreven, al is dat ook niet bepaald noodig. 
Waar bij mij de kantjil den tijger bedriegt, de eerste het nest 'et orgel van zijn heer noemt, en hijzelf zorg draagt eerst uit de buurt te wezen, heeft GF. $n^{\circ} 2$ : dat de landschildpad den aap beetneemt, het nest 's konings gong voorstelt, de bedrieger vooraf zorgt weg te komen; PT. $n^{\circ} \mathrm{I}$ : dat de aap de antilope fopt, het nest een trommel heet van den vorst, en de antilope zich eerst door onder water duiken van de bijen bevrijdt; ST. $\mathrm{n}^{\circ}$ II $b$ : dat de aap den reus beetneemt, en het nest de fluit van mevrouw verbeeldt; de preanger dongeng: dat de schildpad den aap fopt; de bantensche evenzoo, beide dus hierin overeenstemmende met GF. $n^{\circ} 2$; het nest heet in 't bantensch verhaal de $g$ ong van Batara Goeroe; Pk. $n^{\circ} 5$ heeft: dat de plain $\mathrm{d}^{5}{ }^{5}$ 't op den tijger munt - als in mijn verhaal - en het nest doorgaat voor den gōng van radja Thlimēm; P. II n ${ }^{\circ}$ 7: dat de pelandoek er den aap doet inloopen, en het nest voor de zieldoos van den (jongen) pelandoek wordt uitgegeven.

Slechts dit is mij bekend geworden uit de geraadpleegde werken, en of Na. $n^{\circ}$ 14 (Kalila dan Damina e d. Gonggrijp, bl. 265) "de aap en de zeeschildpad" hierbij behoort, weet ik niet. -

Dat het bedrog met het wespennest niet het eenige is waarbij tot middel een zoogenaamd muziekinstrument strekt, bewijzen: K. I $n^{0} 3$, het verhaal behelzend hoe 's tijgers tong wordt afgeknepen tusschen de stengels van een bamboe-doeri-stoel, door kantjil "de trompet van Nabi Soleman" geheeten, "die als een gamĕlan, heerlijk klinkt"; en ST. nos II $c$ en $f$, waarin de oliepers die den aap tot kwelmiddel van den reus strekt, door hem "de fluit mijner Meesteres" wordt genoemd. (K. II $\mathrm{n}^{\text {ss }} 8$ en 9 behoeven geene vermelding in dit verband, wijl er het bedrog met den b a m b o e-struik als muziekinstrument geheel in op den achtergrond is geraakt.) -

Het bedrog met de slang - mijn verhaal $\mathrm{n}^{\circ}$ II $c$ - wordt in den fabelschat van den archipel haast even vaak aangetroffen als het vorige. Ik vind het toch in de fabelen van Sangir, Galèla, Java en Atjeh. Hier komt zich nu eene maleische voordraging van Singapoera bijvoegen.

De sprekende trekken in deze laatste zijn: dat de slang het kistje der vorstin heet, dat er op gezeten wordt, dat de kantjil vooraf zorgt ver weg te zijn, en dat de slang den tijger bijt, ' - 
die er de helft van zijn uitwendig schaamdeel mee verliest. ST. $\mathrm{n}^{\circ} \mathrm{II} l$ verhaalt: dat de slang volgens den aap de gordel van mevrouw is, dien dan de reus omdoet, waarop zij dezen bijt; ald. $\mathrm{n}^{0} \mathrm{II} c$ : dat de slang "de gordel mijner Meesteres" is - naar de aap zegt -, in wiens kronkel dan de reus gaat zitten, om daarop door haar gewrongen te worden; ald. $\mathrm{n}^{0}$ II $f$ heeft behalve deze zelfde trekken nog: dat de aap zich vooraf buiten bereik stelt, want er staat nadat de gebeurtenis verhaald is: "Daarop vluchtte de aap weder verder weg naar boven." In GF. n 2 noemt de landschildpad de slang 'skonings gordel, doet de aap dien om, nadat de schildpad zich eerst behoorlijk verwijderd heeft, en bijt en wringt de slang dan den aap. Volgens K. I n 2 noemt kantjil het reptiel den slanggordel van nabi Soleman, zorgt hij van te voren uit de voeten te zijn, doet de tijger den zoogenaamden gordel aan, en moet dan een hevigen aanval van de slang weer- en een hevig gevecht met haar doorstaan. In K. II n $n^{\text {os }} 8$ en 9 is de slang ook een gordel en doet de banteng dien door toedoen van het dwerghert om. Pk. $n^{\circ} 5$ verhaalt dat de pland $\bar{o}^{\varsigma}$ de slang radja Thlimeum's hoofddoek" noemt; en de daar vermelde bantensche dongeng - waarin de schildpad den aap bedriegt - dat de slang de gordel is van Batara Goeroe, terwijl daarin de vernieling van des aaps testikels wel mede voorkomt, maar als een van het avontuur met de slang afgescheiden verhaal.

De wijze waardoor de tijger gebeten wordt, t. w. zitten gaande op de slang die juist haar bek open houdt, wekt de herinnering op aan RdV. II bl. 104, beschrijvende hoe de zich dood houdende Reinaart de vrouw van den raaf tot in zijn opengesperden muil laat naderen om haar daarop onvoorziens in den nek te bijten.

Van die testikelgeschiedenis valt, na het vroeger naar aanleiding daarvan oṕgemerkte, toch nog wat te zeggen. Immers hetzelfde motief treft men aan in RdV. I v. 1153 vlgg.: de gestropte kater springt in zijn raadloosheid den in zijn hemd staanden pastoor naar diens "beurze zonder naad" en bijt hem zijn eenen testikel af. K. I no 7 heeft ook een dergelijk verhaal met heuglijker afloop: de krokodil, dien het dwerghert reeds eenmaal had bedrogen en op den kop getikt, en dien het nu weer bedrogen heeft, weet zijn uitwendig schaamdeel te grijpen, maar kantjil weet hem van zijn heilloos voornemen af te brengen door te beweren dat zijn scrotum den hem toevertrouwden "geldtasch van Nabi Suleman" is. Blz. 426 noot 9 van "Het looze dwerghert" door J. van Dissel, Indische Gids 6e Volgr. VII. 
1899, deel I, vermeldt het maleische sprookje van den "Aap en den Boomstam" met zijn sanskritschen grondtekst; deze laatste behelst dat de aap sterft tengevolge der verbrijzeling zijner testikels door het terugspringen van de wig die den hem tot zetel verstrekkenden boomstam opengespalkt hield: de aap in den bantensehen dongeng weerstond deze ramp voorspoediger, als voren bleek.

De voorzorg van den kantjil om steeds vóór zijn bedrog aan het licht komt uit de voeten te zijn, doet zich behalve in de reeds genoemde parallelle verhalen ook voor in $\mathrm{K}$. $\mathrm{I}^{0} \mathrm{l}$, behelzende het bedrog met den buffelbolus: bij de toestemming die kantjil den tijger geeft om hem te eten bedingt hij zich eerst te mogen verwijderen; en in $K$. II $n^{\circ} 12$, verhalende hoe kantjil den kebodanoe aan 't waringin-vruchtjes tellen zet: alvorens deze er achter komt in 't ootje te zijn genomen heeft kantjil zich weggespoed. -

Zoo ben ik nu aan het putverhaal toe. Putten doen veel dienst in de dierfabel. In $R d V$. I v. 2346 vlgg. leest men in de uitlegging die Reinaart aan koning Nobel geeft van de plaats waar de laatste koning Ermelinks schat kan vinden van een Krekelput. Als "borne" was deze een natte put. Evenwel doet deze put niet zoo erg mee, wat echter wel 't geval is met den natten put waarvan sprake is in $\mathrm{K}$. I $\mathrm{n}^{0} 11 d$ en $\mathrm{K}$. II $\mathrm{n}^{0} 5$, waarin naamlijk resp. de wedoes-proetjoel en de kantjil den tijger zijn kop laten zien, hem in den waan brengend dat het beeld daarvan het restantje is van een zoo juist door den wedoes, resp. kantjil opgegeten tijger. Een andere natte put komt voor in ST. n ${ }^{\text {os }}$ II $c$, IIf en III. In het eerstvermelde nummer noemt de aap, die erbij is gaan zitten, hem "den put mijner Meesteres", hoewel bet een groot meer is, waarin de reus graag wil baden, wat op zijn dood uitloopt; $\mathrm{n}^{\circ}$ II $f$ verhaalt van een put met eene wijdte van ongeveer zeven vadem, dien de daarbij zittende aap den zelfden naam geeft als in $n^{\circ} \mathrm{II} c$, en waarin de reus - wien, tengevolge van zijn vroeger kenbaar gemaakt verlangen om evenals de aap roode billen te hebben, door dezen een roodgloeiend ijzer in zijn zijde is gestoken (RdV. I v. 1376/7 wordt ook de wolf geschroeid!) — wil baden, doch als het ijzer dan gaat sissen, omkomt; $\mathrm{n}^{\circ}$ III komt - behalve dat met het bilschroeiverhaal nog dat van de oliepers wordt vereenigd - geheel met het vorige overeen; ook in zoover dat er de reus voor leniging van de schroeipijn naar het water schijnt te snak- 
ken, hierin zich ansluitend: bij de antilope in PT. $\mathrm{n}^{\circ} \mathrm{I}$, die om van de bijen bevrijd te raken, te water gat; het hertzwijn in datzelfde verhaal, dat evenzoo doet, na door den aap bedrogen, spaansche peper te hebben gegeten; en den beer in RdV. I v. 781, die ontveld en geranseld een gunstig oogenblik te baat neemt om, ter ontkoming aan meer leed, de rivier in te springen en weg te zwemmen.

De vier putverhalen in K. I $n^{0} 9, K$. II $n^{\circ} 3, P$. I $n^{\circ} 2$ en P. II $n^{\circ} 2$ hebben van allen de sterkste overeenkomst met het mijne. Dit blijkt het best door opnoeming der voornaamste trekken van dit laatste: de kantjil begeeft zich in den put om er den tijger in te krijgen; hij beweert dat het einde der dingen nabij is, als wanneer de aarde omgekeerd zal worden; hij gebruikt den tijger als tusschensport om er zelf weer uit te komen; daarna jouwt hij van boven af den tijger uit: en de tijger komt in den put om. In dit verhaal als in de volgende vier is de put een droge. Volgens K. I en II resp. nos 9 en 3 valt het dwerghert er onwillens in; verkondigt het den toevallig er bij komenden dorstigen olifant, resp. banteng: den een aanstaanden hemelval en menschenverplettering, den ander aanstaande aaneensluiting van hemel en aarde; komt het er via den rug van elk dezer dieren weer uit, en jouwt elk hunner van boven af uit; olifant noch banteng komen echter om. In P. I en II, beide $\mathrm{n}^{\circ} 2$, wordt de put met voordacht door het dwerghert gegraven - met behulp zelfs van den te bedriegen reus - ; nadat het dien, in het eerste verhaal, verlokt heeft door het oproepen van vrouw en kinderen en het wijzen op de zich voortbewegende wolken om zich voor den aanstaanden hemelval te bergen; en, in het andere verhaal, door de voorspelling dat de wereld vergaan zal, op welken dag een reus van zijn naam tot hem zou komen; de reus komt dan alleen in den put, zoodat het uitspringen van den pelandoek vervalt; voor het uitjouwen komt dan in de plaats de oproep der geiten en tijgers - van het hoofd des reuzen gedaan — om den reus te slaan, wat zij doen, hem tevens bevuilende; de reus komt dan in den put om, in P. II $\mathrm{n}^{\circ} 2$ verdrinkende in het tijgers- en geitenvuil, - waardoor de put hier meteen te beschouwen is als het tusschen-type der in de dierfabel voorkomende droge en natte putten.

Aan deze verhalen moeten er nog een paar worden toegevoegd, waarin ook het putmotief als reddingsmiddel van den bedrieger is gebruikt. Vooreerst dat van RdV. II bl. 169 vlgg.: Reinaart is door in den eenen van een met een ketting over een katrol saamver- 
bonden paar emmers van een waterput te gaan zitten daarin afgedaald en lokt nu - voorgevende dat het daarbeneden droog is en vischrijk - de wolvin in den anderen emmer, waardoor zij zakt, hij stijgt; en bevrijd zijnde lacht hij haar dan uit. Dan dat van K. II $\mathrm{n}^{\circ}$ 6: de tjel en g-jongkjes door den $\mathrm{kantjil}$ gedood zijnde, spoort hun moeder dezen op en vindt hem bij een put zitten, alwaar de zeug hem te lijf wil, doch - zegt de kantjil neem liever mijn jonger broertje in den put. "De tjeleng springt er in; zoodat de guit weer vrijloopt." Ten slotte luidt de omschrijving van $\mathrm{Pk} . \mathrm{n}^{\circ}$ 20: "De olifantvorst in den put (geheel anders dan het gelijknamige verhaal in Jav.)", enz. Onder "Jav." is hier te verstaan de beide javaansche kantjil-boeken. Op de episode van Reinaart en de wolvin wees reeds de vorengenoemde aankonkondiger in Indische Gids 1890. Bij De la Fontaine wordt ook verhaald, in fabel 5 van boek 3 , hoe de in een put terecht gekomen vos door list den bok bij zich weet te lokken, dien hij dan met horens en al als ladder bezigt om zelf verlost te raken, hem daarna uitjouwend van den bovenrand. Dr. W. G. C. Bijvanck had de vriendlijkheid hierop mijn aandacht te vestigen.

Reeds werd het oog gericht op den trek dat de kantjil na zich ten koste van den tijger bevrijd te hebben, dezen uitjouwt. Evenzoo doet RdV. I Reinaart: den beer als die in den honingeik geklemd zit (v. 664 vlgg.), en als hij hem afgepijnd aan den stroomkant terugvindt (v. 851 vlgg.), den kater als die gestropt is (v. 1106 vlgg.), de pastoorsvrouw als haar man half ontmand is (v. 1177 vlgg.), en de aan haar achterpooten ontschoeide wolvin (v. 2629 vlgg.); RdV. II bl. 116/7 den wolf wanneer die een trap beet heeft van 't zwaar beslagen paard; K. I kantjil den baja's na hen als een brug over het gezwollen water te hebben gebruikt $\left(\mathrm{n}^{\circ} 6\right)$, en een hunner na door een bedrieglijk praatje aan diens scrotum-beet te zijn ontkomen $\left(n^{\circ} 7\right) ;$ de aap het vrouwtje van den kidang, dat door zijn toedoen in den strik is geloopen $\left(\mathrm{n}^{\circ} 12 c\right)$; en GF. $\mathrm{n}^{\circ} 1$ de zelfde de kaailui over wier rug hij de rivier over kwam.

De profetische aanmatiging van het dwerghert is, behalve in de bovengenoemde fabelen, ook een motief in de volgende: GF. $\mathrm{n}^{\circ} 3$, waar de aap het nabijzijnd einde der wereld jegens den reus als fopmiddel toepast; terwijl het dwerghert in P. I en P. II, beide $\mathrm{n}^{0} 1$, tegenover de in veete levende levende geiten en tijgers zich daarvan bedient (het aldaar in den pantoen- 
laatsten regel - voorkomende عُد zal wel دن woeten worden gelezen?); ook in K. II $n^{0} 13$ de episode bevattende dat op kantjil's voorgeven van de nadering des oordeelsdags, de slang zich laat binden. In K. II $n^{\circ} 12$ had $k$ antjil jegens den $k$ ebodanoe als bedriegmiddel reeds aangewend dat de komst van $\mathrm{nabi}$ Soleman in eigen persoon te wachten stond, terwijl alweer een ander fopmotief van profetischen aard gevonden wordt in $\mathrm{K}$. I $\mathbf{n}^{\circ} 5$ en K. IL $n^{\circ} 14$, te weten dat er op bevel van nabi Soleman eene groote overstrooming na op handen is. Opmerklijk is dat in K. II $a^{\circ} 15$ de kantjil - in dit geheele boek een wonderbaarder figuur dan in K. I - eene waarschuwing voor hem naderend onheil door eene stem uit den hemel ontvangt, waardoor zijne betrekking tot den hooge op deze plaats althans niet voorgewend maar werklijk-bestaande is.

Evenals in mijn onderhavig verhaal de tijger omkomt, heeft in de fabel - ook hierin zich niet van de natuur verwijderend - vaak een sterfgeval plaats: ST. $n^{\circ}$ II $c$, II $f$ en III benevens PT. $\mathrm{n}^{0} 2$ boden ons er al voorbeelden van in de persoon van den reus; $\mathrm{RdV}$. II blz. 104 in die van de ravin; en het sanskritsche verhaal van den aap en den boomstam in die van den aap. Het in PT. $n^{\circ}$ I zich te water begevend hertzwijn komt ook daarin om. Overigens wijs ik nog op de boven genoemde gevallen dat er jungkjes van dieren omkomen, ja zelfs een menschenkind, en dan - omdat dit zoo aan den inhoud van mijn verhaal in kwestie doet denken - op Na. $n^{\circ} 7$ (Kalila dan Damina ed. Gonggrijp bl. 78): "De keureukö̈h (verklaard als pland $\bar{o}^{5}$ ) doodt den tijger" - waar in de verwijzing naar $\mathrm{Pk} . \mathrm{n}^{\circ} 10$ worde gelezen " $\mathrm{n}^{\circ} 19 "$ - en eindlijk op K. II n 18 waarin de kantjilzelf sterft. -

En nu zij overgegaan tot het laatste mijner verhaleu. Hier treedt het dwerghert op met menschen, wier kost het opeet, wat aanleiding geeft dat het in een kippenben gesloten wordt, om 's anderendaags geslacht te worden, aan welk noodlot het evenwel ontkomt.

Dat gezamenlijk optreden van menschen met dieren treft men ook aan in K. II $n^{0} 18$, waarin kantjil -- hier eigenlijk een verkapt mensch - in gesprek komt met de egyptische koningsdochter; GF. $\mathrm{n}^{\circ} 9$, waarin een slang met een menschenhoofd met een mensch aan 't praten is - tegenover de menschslang hier heeft ST. II $c$ en $f$ een menschhaai: totemistische uitdenksels! - 
ST. $\mathrm{n}^{\circ}$ VIII, waarin een aap en een haagdis met een vorstlijk gezin beurtlings gesprekken voeren; ald. $\mathrm{n}^{\circ} \mathrm{X}$, waarin de garnaal met eene oude vrouw praat (blijkens de bijgevoegde aanteekening mede voorkomende onder de Sea-fabels van dr. Riedel in Tijdschr. Bat. Gen. dl. 17); PT. no III, waarin eene vrouw en haar man resp. met een krokodil en een haagdis een onderhoud hebben, welke krokodil een menschkrokodil is, en dus als derde aan de beide vorige menschdieren moet worden toegevoegd; ald. $\mathrm{n}^{0} \mathrm{IX}$, waarin een mensch tegen de mieren het woord voert. Rekent men hiertoe ook de verhalen waarin het gen us mensch vertegenwoordigd wordt door den overmensch, als reus dan wel als setan, dan zijn er nog etlijke nnmmers aan toe te voegen.

Overeenkomst, ook in de fijnere trekken, heeft mijn verhaal met K. I $n^{0} 4$ en $K$. II $n^{0} 1$, waar het ook 's dwergherts verorberen van mensehenkost - hier echter te velde staande - is die hem, evenzeer om 's andrendaags geslacht te worden, in den k o e roe n ga n brengt, zonder dat dit oordeel, en wel mede door tusschenkomst van een ander dier, aan hem voltrokken wordt. In K. I n n $^{\circ}$ raakt kantjil door vastkleven aan een vogelverschrikker - zie hierbij P. II $\mathrm{n}^{\circ} 6$, waarin de krokodil gevangen wordt door vastplakken aan een plauk-, in K. II $n^{0} 1$, evenals in K. II $n^{0} 18$, in een strik gevangen.

Zich aansluiten bij deze javaansche k oeroengan-verhalen, doch sterker direkt bij het mijne, doen de verhalen in $\mathrm{K}$. I $n^{\text {os }} 12 b--d$ en $14 g$, welke onderling nagenoeg gelijk zijn. Hier wederom dat zich te goed doen aan moeskruid van menschen, dat vastraken in den strik - in $n^{\circ} 12 c$ het wijfje van den kidang, in $n^{\circ} 14 g$ de kidang-zelf - , maar dan het raad ontvangen van een welgezind en slim dier, strekkende om zich schijndood te houden - waarbij gezegde raadgever hem nog zorgt te bevuilen oun beter dood te lijken - wat de bévrijding van 't gevangen kreatuur dan eveneens ten gevolge heeft, en wel door den gevangennemer-zelf. Het

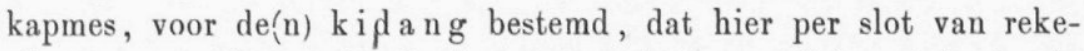
ning een ander treft, herinnert aan het voor Reinaart bestemde tafelmes van den pastoor in RdV. I v. 1435, dat den wolf in 't oog terecht komt, een ramp die het slot vormt van een avontuur waarin beide dieren zich ook aan menschenkost - Reinaart bepaaldlijk aan toebereide - zich hadden vergrepen.

Hier laat zich de vergelijking verder voortzetten : het binnengaan van een huis door een bovenopening om roof machtig te worden 
doet er op Reinaarts aanstichting de wolf, - wat eveneens tot het opdagen van alle inwonenden leidt, - en een pak slaag voor den wolf die omlaag ploft (v. 1466-1501) - men vergelijke PT. $\mathrm{n}^{\circ} \mathrm{I}$ met zijn van boven zich naar beneden stortenden aap-; zelf blijft Reinaart altijd vrij van toetakeling door menschen (en dieren), maar evenals in mijn verhalen de tijger en de bruid er slecht afkomen, zoo is dit - zij 't ook in ander opzicht - in RdV. I 't geval met den wolf (zie o. m. de reeds genoemde gevallen), den beer (v. 718 vlgg.) en den ram (v. 3156); ja, ook hier weet hij, reeds geöordeeld zijnde, aan zijn lot te ontkomen (v. 1736-3048).

In Pk. $\mathrm{n}^{0} \mathrm{l}$ schijnt in het verhaal "De pland $\bar{o}^{\varsigma}$, de kikvorsch, de tuineigenaar en de hond", blijkens de bijvoeging "(dergelijk in Jav.)" het atjehsch verhaal vervat te zijn, dat in meerdere of mindere mate zich bij het mijne in kwestie betrekken laat, en is dat zoo dan behoort hier tevens gewezen te worden op het overeenkomstige verhaal in den t.a. p. gemelden bantenschen dongeng, waarin evenwel de aap de rol van den kikvorseh en den hond en de schildpad die van het dwerghert vervult.

Bij ontstentenis van kennis aangaande den verderen inhoud van het atjehsche verhaal kan ik slechts vermoeden dat daarin de kikvorsch in gelijke kwaliteit als in mijn verhaal optreedt; van nog een paar atjehsche fabels zou ik zelfs dat vermoeden niet zoo grif durven uiten; deze zijn: Pk. no 8 "De pland $\bar{o}^{\varsigma}$, de kikvorsch, de leguaan, het kreng, de hond, de tijger, de twee buffels, de twee tijgers, de olifant en de menschen,, en Na. $n^{\circ} 13$ (Kalila dan Damina ed. Gonggrijp, bl. 260) "De slang en de kikvorschen." Te wijzen valt echter op GF. $n^{\circ} 6$, waarin - gelijk al boven bleek - de kikvorsch zich doet kennen als een knap dier, een dier waar wat in zit, springles geven als hij daar immers doet aan den klabang. Eigenaardig is het in ST. ${ }^{\circ}$ XIV, ten aanzien der vraag: hoe de kip de slang kan treffen die hare kiekens heeft opgegeten, als raadsman - en goed raadsman ook - te zien optreden de hond, hetzelfde dier dat in de javaansche koeroengan-verhalen zich van zoo'n beklaaglijk domme zijde doet kennen.

"De rol, die de Aap in de Sangireesche volksverhalen speelt, is die van den Kantjil in het Javansche dierenepos, die van den Pělandoek in de Maleische dierenfabel", zegt dr. Adriani, ST. bl. 349 , en behalve in den door hem bedoelden zin gat dit ook op in zooverre dezelfde vraatzucht die in mijn onderhavig verhaal de $\mathrm{k}$ a ntjil ten toon spreidt en in RdV. I en II "de felle metten roden 
baerde", in ST. nos II $b, c$ en $f$ door den aap betoond wordt, die zich daar immers neester maakt van het eten van den reus, welke echter op zijn beurt de vraatzucht verpersoonlijkt in ST. $\mathrm{n}^{\circ}$ III, K. I $\mathrm{n}^{\circ} 5$, P. I $\mathrm{n}^{\circ} 9$, P. II $\mathrm{n}^{\circ} 2$ en GF. $\mathrm{n}^{\circ} 3$. In GF. bl. 194 zegt de heer Van Baarda: "Voorts ziet men trekken van overeenkomst in de Fabelen, waarin de Aap optreedt, tusschen de door Dr. Adriani uitgegeven "Sangireesche Teksten".... en deze Galèlareesche...." Voor zoover den trek van des aaps vraatzucht betreft verwijs ik naar GF. $\mathrm{n}^{0} 2$.

Kantjil legt het in mijn verhaal een oogenblik af. Zulke onmachtige momenten kennen K. I en K. II - gelijk wij zagen ook voor hem. Daarbij voegen zich in dit verband nog de verhalen K. I $n^{\circ} 8$ en K. II $n^{\circ} 2$, verhalende hoe het dwerghert in slimheid overtroefd wordt door de slakken die den wedloop tegen hem hebben aangegaan, welke fabel onder de GF. voorkomt sub $n^{\text {os }} 12,13$ en 14 , resp. van het hert, het strandloopertje, en den ijsvogel tegen de zeeslak, verrijkt met eene belangrijke aanteekening in de noot omtrent haar voorkomen in Duitschland, bij de bakwiri's van Kameroen en de betjoewanen van Zuid-Afrika.

De list om zich schijndood te houden, door ons reeds buiten mijn verhaal in K. I $\mathrm{n}^{\text {os }} 12 d$ en $14 g$ aangetroffen, hebben ook: GF. $\mathrm{n}^{0} 1$, waarin de kaaiman haar uit eigen beweging tegen den aap toepast, dien hij er wil laten inloopen - wat niet lukt -; en RdV. II bl. 104, behelzende Reinaarts toepassing van dezen streek, ook uit eigen vinding, tegen het ravenpaar - met gewenschten uitslag. In ST. $\mathrm{n}^{\circ}$ VIII houdt de koning zich schijndood, op raad van de hagedis, waardoor de apen in de val loopen. PT. $n^{\circ}$ III bevat ook zulke hagdis-bijstand aan menschen - dr. Juynboll verwijst daarbij naar prof. Wilken's studie over dit dier in Bijdr. kon. inst. deel 40 - en hieraan is toe te voegen ST. $\mathrm{n}^{\circ} \mathrm{I}$, bl. 332 , in het midden. -

Weggegooid worden schijnt den $\mathrm{kantjil}$ geen kwaad te doen: in mijne $n^{\text {os }}$ II $b$ en $c$ laat hij het zich doen, hier - in $n^{\circ}$ II $e$ -- wordt hij het gedaan. Evenzoo wordt in ST. $n^{\circ} \mathrm{X}$ het lijk der oude vrouw in het bosch, in RdV. I v. 1459 de lamgeslagen wolf in de gracht gegooid. - 